\title{
Source regions of some persistent organic pollutants measured in the atmosphere at Birkenes, Norway
}

\author{
S. Eckhardt ${ }^{1}$, K. Breivik ${ }^{1,2}$, Y. F. Li ${ }^{3,4}$, S. Manø ${ }^{1}$, and A. Stohl ${ }^{1}$ \\ ${ }^{1}$ Norwegian Institute for Air Research, P.O. Box 100, 2027 Kjeller, Norway \\ ${ }^{2}$ University of Oslo, Department of Chemistry, P.O. Box 1033, 0315 Oslo, Norway \\ ${ }^{3}$ Air Quality Research Division, Science and Technology Branch, Environment Canada, 4905 Dufferin Street, Toronto, \\ Ontario M3H 5T4, Canada \\ ${ }^{4}$ International Joint Research Center for Persistent Toxic Substances (IJRC-PTS), State Key Laboratory of Urban Water \\ Resource and Environment, Harbin Institute of Technology, Harbin, China
}

Received: 3 April 2009 - Published in Atmos. Chem. Phys. Discuss.: 20 May 2009

Revised: 10 August 2009 - Accepted: 22 August 2009 - Published: 11 September 2009

\begin{abstract}
A key feature of POPs (Persistent Organic Pollutants) is their potential for long-range atmospheric transport. In order to better understand and predict atmospheric sourcereceptor relationships of POPs, we have modified an existing Lagrangian transport model (FLEXPART) to include some of the key processes that control the atmospheric fate of POPs. We also present four years (2004-2007) of new atmospheric measurement data for polychlorinated biphenyls (PCBs) and hexachlorocyclohexanes (HCHs) obtained at Birkenes, an EMEP (European Monitoring and Evaluation Programme) site in southern Norway. The model overestimates measured PCB-28 and $\gamma$-HCH concentrations by factors of 2 and 8 , respectively, which is most likely because the emissions used as input to the model are overestimated. FLEXPART captures the temporal variability in the measurements very well and, depending on season, explains $31-67 \%$ (14-62\%) of the variance of measured PCB-28 $(\gamma-\mathrm{HCH})$ concentrations. FLEXPART, run in a time-reversed (adjoint) mode, was used to identify the source regions responsible for the POP loading at the Birkenes station. Emissions in Central Europe and Eastern Europe contributed 32\% and 24\%, respectively, to PCB-28 at Birkenes, while Western Europe was found to be the dominant source (50\%) for $\gamma$-HCH. Intercontinental transport from North America contributed 13\% $\gamma-\mathrm{HCH}$. While FLEXPART has no treatment of the partitioning of POPs between different surface media, it was found a very useful tool for studying atmospheric source-receptor rela-
\end{abstract}

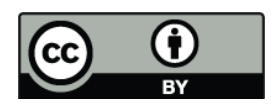

Correspondence to: S. Eckhardt (sec@nilu.no) tionships for POPs and POP-like chemicals that do not sorb strongly to atmospheric particles and whose atmospheric levels are believed to be mainly controlled by primary sources.

\section{Introduction}

Despite of significant emission reductions or bans of many persistent organic pollutants (POPs) over the past few decades, POPs continue to contaminate the environment and accumulate in food chains. Because of their persistence and semi-volatility POPs have a great potential for long-range atmospheric transport which enables them to migrate from the mid latitudes to the Arctic regions, for instance (Wania and Mackay, 1993; AMAP, 1998). In our study we will investigate $\gamma$-hexachlorocyclohexan $(\gamma-\mathrm{HCH})$, which is an insecticide, and polychlorinated biphenyls (PCBs), which are industrial chemicals.

The global production of PCBs was started around 1930, peaked around 1970 and ceased in the early 1990s when the last factories in Russia were closed down (Breivik et al., 2002a). PCBs are now regulated by the Stockholm Convention on POPs (UNEP, 2001) as well as the 1998 Aarhus Protocol on POPs under the Convention on Long-Range Transboundary Air Pollution (CLRTAP) (UNECE, 2009; Tuinstra et al., 2006).

HCHs, which are recognized as POPs under CLRTAP, have been widely used as insecticides in Europe (Breivik et al., 1999) and other parts of the world (Li, 1999a, b; Li et al., 1996, 1998a, b, 2000, 2001, 2003b, 2004, 2008). $\gamma$-HCH occurs in a proportion of 6-10\% in the so-called technical $\mathrm{HCH}$

Published by Copernicus Publications on behalf of the European Geosciences Union. 
mixture and $>99 \%$ in lindane (e.g. Willett et al., 1998). It has been demonstrated in different studies that $\gamma-\mathrm{HCH}$ can be transported over long distances. For example, trans-pacific transport was shown to occur during an aircraft measurement campaign in Canada (Harner et al., 2005) and by model simulation (Zhang et al., 2008).

POPs can partition between the atmosphere and different environmental media such as the oceans, rivers or soils. Differences in partitioning behaviour among POPs reflect differences in their physico-chemical properties and persistence in the various media (e.g., Li et al., 2003a). Some POPs have the potential to undergo reversible exchange between terrestrial or aquatic surfaces and the atmosphere. Of all media, transport of these chemicals from key usage areas to remote regions is fastest in the atmosphere (Halsall, 2004). However, because of the reversible exchange atmospheric transport may occur in several steps, a process commonly known as grass hopping (Wania and Mackay, 1996). Related to this grass hopping is a mechanism known as cold condensation (Wania and Mackay, 1993), by which some POPs are preferably removed from the atmosphere in cold regions and by which they can reach surprisingly high concentrations in the Arctic environment where they can bioaccumulate in animals and humans (AMAP, 1998). Less volatile POPs which sorb strongly to atmospheric particles (high partitioning coefficient $K_{\mathrm{OA}}$ between octanol, a substitute for organic matter, and air) or which dissolve easily in rain droplets (low partitioning coefficient $K_{\mathrm{AW}}$ between air and water) tend to have a more limited potential for long range atmospheric transport, whereas semi-volatile species can be transported over long distances in one or more steps towards the Arctic region (e.g. Wania and Mackay, 1993; Semeena and Lammel, 2005; Wania, 2006).

Following reductions in primary emissions of POPs as a result of control strategies, one may expect that the relative importance of secondary re-emissions from various environmental storage reservoirs is becoming increasingly important in controlling contemporary atmospheric concentrations. For example, re-volatilization from soils was suggested as the key source of PCBs to the UK atmosphere in the early 1990s (Harrad et al., 1994), and forest and agricultural fires were discovered as an important source for enhancements of POP concentrations in the Arctic (Eckhardt et al., 2007). However, other studies suggest that the atmospheric levels in both urban (Jamshidi et al., 2007) and remote areas (Hung et al., 2005) can still be explained mainly by primary emissions. Thus, considerable uncertainties remain about the relative importance of primary and secondary sources of POPs in controlling the atmospheric burden, and thus also the number of "hops" these chemicals can make during transport to remote areas (Semeena and Lammel, 2005).

There are two classic approaches to model the distribution of POPs (see e.g. Hansen et al., 2006). Multi-compartment models use just limited meteorological data but include detailed descriptions of the partitioning of the species within and between the different environmental media (Mackay, 2001), while chemistry transport models have a detailed treatment of transport and chemistry in the atmosphere but a rather simple description of the compartments other than the atmosphere (Ma et al., 2003; Gong et al., 2007; Huang et al., 2007). The multi-compartment models have been successful in describing the global distribution of POPs and their longterm environmental fate in the various compartments (Wania and Su, 2004; Wania and Daly, 2002). They typically cannot be compared to individual atmospheric measurements as they are based on averaged meteorological data. However, several climatological studies (e.g., based on 70 years NCEP reanalysis data) were performed with multi compartment models. For instance, MacLeod et al. (2005) compared their model results with measured annual PCB concentrations at 11 monitoring stations and found good agreement. For studying transport episodes, chemistry transport models that use actual meteorological data with high space and time resolution are better suited (Ma et al., 2005; Zhang et al., 2008). Unfortunately, not many direct comparisons between model results and measurement data have been made to date (Hansen et al., 2004).

Simple trajectory models have often been used for identifying the sources of the measured POPs during actually observed episodes of enhanced POP concentrations (Du and Rodenburg, 2007; Venier and Hites, 2008; Hafner and Hites, 2008). Trajectories describe the atmospheric transport pathway in a simplified way (e.g., they lack turbulence and convection parameterizations) and ignore chemical processes (e.g., chemical transformations, wet and dry deposition) entirely. Therefore, they can only be used in a qualitative way to identify potential source areas.

In this study we present a model that is based on a Lagrangian particle dispersion model, FLEXPART. While the modified version of FLEXPART used herein also has an extremely simple treatment of the partitioning between environmental compartments, it has a detailed treatment of atmospheric transport (including turbulence and convection), wet and dry deposition, and includes simple linear chemical transformations such as the removal of POPs by hydroxyl $(\mathrm{OH})$ radicals. As such, FLEXPART is intermediate in complexity between simple trajectory models and comprehensive chemistry transport models. The model has the special advantage that it can be run backward in time (in adjoint mode) to identify the source regions of POPs measured at a station. We use the model to investigate the sources of PCB-28 and $\gamma$-HCH measured at the EMEP station Birkenes in southern Norway, following an evaluation of the model performance. The modelling strategy presented herein, with its emphasis on understanding and predicting individual episodes, is considered complementary to operational models used to assess climatological source-receptor relationships for POPs within EMEP under CLRTAP (e.g. Malanichev et al., 2004). 


\section{Methods}

\subsection{Model}

Simulations of atmospheric POP transport were made using the Lagrangian particle dispersion model FLEXPART (Stohl et al., 1998, 2005; Stohl and Thomson, 1999) (see http://transport.nilu.no/flexpart). FLEXPART has been validated with data from continental scale tracer experiments (Stohl et al., 1998) and was used previously to study the transport of biomass burning and anthropogenic emissions between continents (e.g., Stohl et al., 2003) and into the Arctic (e.g., Eckhardt et al., 2003; Stohl et al., 2006). The main purpose of FLEXPART model simulations is typically to identify the sources of the measured pollution and to quantify removal from the atmosphere occurring on the way. In this study, FLEXPART was driven with analyses from the European Centre for Medium-Range Weather Forecasts (ECMWF, 1995) with $1^{\circ} \times 1^{\circ}$ resolution (derived from T319 spectral truncation). Analyses at 00:00, 06:00, 12:00 and 18:00 UTC, and 3-h forecasts at 03:00, 09:00, 15:00 and 21:00 UTC were used. There are 23 ECMWF model levels below $3000 \mathrm{~m}$, and 91 in total.

FLEXPART calculates the trajectories of so-called tracer particles using the mean winds interpolated from the analysis fields plus random motions representing turbulence. For moist convective transport, FLEXPART uses the scheme of Emanuel and Živković-Rothman (1999), as described and tested by Forster et al. (2007). A special feature of FLEXPART is the possibility to run it backward in time. The FLEXPART backward calculations were described in detail by Stohl et al. (2003) and Seibert and Frank (2004) and, therefore, only a brief summary is given here. Backward (adjoint) simulations from the Birkenes station (marked with a white circle in Fig. 12) were made for each measurement sample which was taken during the period from 2004 to 2007. For each sample, 40000 particles were released at the measurement point and followed backward in time for 50 days to calculate an emission sensitivity (ES) function (Seibert and Frank, 2004). The ES value (in units of s) in a particular grid cell is proportional to the particle residence time in that cell and gives the simulated concentration at the receptor that a source of unit strength $\left(1 \mathrm{~kg} \mathrm{~s}^{-1}\right)$ in the cell would produce. Of particular interest is the ES close to the surface, as most POP emissions occur near ground. Thus, we calculate ES-values for a so-called footprint layer $0-100 \mathrm{~m}$ above ground. Folding (i.e., multiplying) the footprint ES with the emission flux densities (in units of $\mathrm{kg} \mathrm{m}^{-2} \mathrm{~s}^{-1}$ ) taken from an appropriate emission inventory yields the geographical distribution of sources contributing to the simulated concentration (in units of $\mathrm{kg} \mathrm{m}^{-3}$ ) at the receptor. Areal integration of these emission contributions (EC) gives the simulated concentration at the receptor. The emission inventories used are described in Sect. 2.2. Notice that the calculation of emission sensitivities and emission contributions is independent of the measurement data. The model results could be combined with the measurement data for inverse modeling. However, this is not done here because of insufficient data and the measurements were used only for model evaluation and a simple scaling of the emissions in Sect. 6.

In the past, FLEXPART backward calculations were performed assuming that no removal occurred en route (e.g. Eckhardt et al., 2007). However, if the substance considered is removed by chemical reactions or dry and wet deposition, the total ES per time interval decreases backward in time, whereas it would remain constant for a passive tracer. Since FLEXPART is a linear model this can be accounted for in a backward simulation in the same way as in an analogous forward simulation (Seibert and Frank, 2004). We have considered here removal by the reaction with hydroxyl $(\mathrm{OH})$ radicals, as well as both dry and wet gaseous deposition.

Removal by reaction with $\mathrm{OH}$ (Eq. 1) is an important loss process in the atmosphere for several POPs (e.g. Anderson and Hites, 1996; Brubaker and Hites, 1998). Reaction rates taken from the literature, actual temperature, and a climatological monthly averaged $\mathrm{OH}$ field given at eight height levels with a $3^{\circ}$ latitude $\times 5^{\circ}$ longitude resolution (Bey et al., 2001) are used to calculate the POP removal.

For PCB-28 and $\gamma-\mathrm{HCH}$, reaction rates at $25^{\circ} \mathrm{C}\left(k_{A \text { ref }}\right)$ of $1.1 \times 10^{-12} \mathrm{~cm}^{3}$ molecules ${ }^{-1} \mathrm{~s}^{-1}$ (Anderson and Hites, 1996) and $1.9 \times 10^{-13} \mathrm{~cm}^{3}$ molecules ${ }^{-1} \mathrm{~s}^{-1}$ (Brubaker and Hites, 1998) have been used, respectively. The loss rate $k_{A}$ in $\mathrm{s}^{-1}$ at a particular temperature $T$ (in $\mathrm{K}$ ) and $\mathrm{OH}$ radical concentration $[\mathrm{OH}]$ (in molecules $\mathrm{cm}^{-3}$ ) is determined from

$k_{A}=k_{\text {Aref }}[\mathrm{OH}] e^{\left(\frac{E_{A}}{R}\right)\left(\frac{1}{T_{\mathrm{ref}}}-\frac{1}{T}\right)}$

where $k_{A r e f}$ is the reaction rate constant at the reference temperature $T_{\text {ref }}$ in $\mathrm{cm}^{3}$ molecule ${ }^{-1} \mathrm{~s}^{-1}$ as given above, $R$ is the gas constant $\left(8.314 \mathrm{~J} \mathrm{~K}^{-1} \mathrm{~mol}^{-1}\right)$ and $E_{A}$ is the activation energy of the reaction, which is set to $10000 \mathrm{~J} \mathrm{~mol}^{-1}$ (Atkinson and Aschman, 1985; Wania and Daly, 2002).

Dry gaseous deposition is calculated based on the resistance method as described in Wesely (1989), which is often used for classical pollutants like $\mathrm{O}_{3}$ and $\mathrm{SO}_{2}$, but also for mercury and POPs (Mackay, 2001; Semeena and Lammel, 2006). Substances are characterized in terms of their reactivity relative to that of ozone, molecular diffusivity in air and solubility in terms of their Henry's law constant. Based on these properties and meteorological parameters, the aerodynamic resistance $r_{a}$, quasilaminar sublayer resistance $r_{b}$ and bulk surface resistance $r_{c}$ are calculated, from which deposition velocities $\left(v_{d}\right)$ can be derived according to

$v_{d}=\frac{1}{r_{a}+r_{b}+r_{c}}$

Diffusivity values for the substances were set to $0.05 \mathrm{~cm}^{2} / \mathrm{s}$ as taken from Cousins et al. (1999), Henry's law constants are 33.1 (PCB-28) and $0.24(\gamma-\mathrm{HCH}) \mathrm{Pa} \mathrm{m}^{3} \mathrm{~mol}^{-1}$, taken from Li et al. (2003a) and Sahsuvar et al. (2003). 


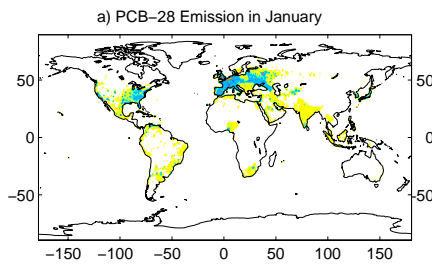
c) PCB-28 Emission in July
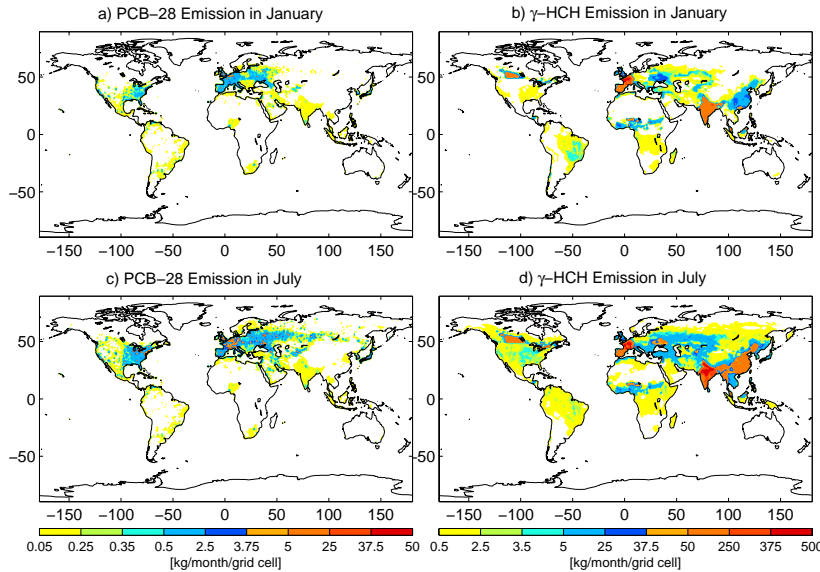
d) $\gamma-\mathrm{HCH}$ Emission in July

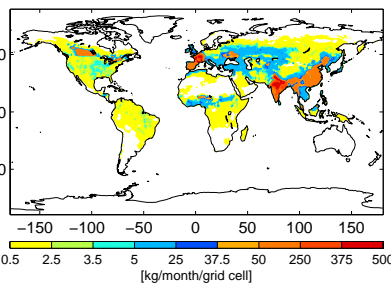

Fig. 1. Monthly emission of PCB-28 (Breivik et al., 2007, high scenario, temperature corrected) and of $\gamma-\mathrm{HCH}$ (Li et al., 2008) for January and July 2005. The emission fluxes on the logarithmic scale are given in $\mathrm{kg} / \mathrm{month}$ per $1^{\circ} \times 1^{\circ}$ grid cell.

Partitioning processes (e.g. gas/particle partitioning) are neglected in FLEXPART. This implies that the FLEXPART model is less suitable to study POPs that are sorbed appreciably to atmospheric particles $\left(\log K_{\mathrm{OA}} \gtrsim 10-11\right.$; Meyer et al., 2005). The model is also not well suited for substances for which atmospheric concentration levels are mainly controlled by secondary re-emissions (e.g., from soils) unless these re-emissions can be accounted for approximately in the emission inventories. As previously discussed, the relative importance of primary and secondary sources in controlling contemporary levels of PCBs in air is poorly understood. Thus, our approach relies on the assumption that primary sources still dominate over secondary sources in controlling atmospheric levels of both PCBs (e.g. Hung et al., 2005; Lohmann et al., 2007) and $\gamma$-HCH. If this is correct, ignoring reversible atmospheric deposition may be acceptable as a first approximation. Real meteorological data is used in this study, which enables us to directly compare measured and modeled atmospheric concentrations. Our approach is thus considered complementary to the model evaluations that have been carried out in the past.

The removal by precipitation (no difference between rain and snow was made) below clouds is parameterized by the scavenging coefficients $A\left[\mathrm{~s}^{-1}\right]$ and the rainfall rate $I$ [mm h ${ }^{-1}$ ] (Eq. 3):

$\Delta=A I^{0.62}$

The scavenging coefficient depends on the diffusivity of the substance. In cloud scavenging depends on the temperature corrected Henry's law constant as well as the actual rainfall rate and cloud height (details in Hertl et al., 1995).

Notice that our emission sensitivity analysis is related to the sensitivity studies performed by Mackay and Reid (2008) using a multi-compartment model. They quantified the sen- sitivity of a POP concentration response in a given box to the emission flux occurring in another box. However, while their sensitivity analysis considered fluxes across compartments, we study only the concentration response in the atmosphere.

\subsection{Emission inventories}

The $\gamma$-HCH emission fluxes were available from the inventory of $\mathrm{Li}$ et al. (2008). $\gamma-\mathrm{HCH}$ has main source regions in France, Spain, Canada, India and Eastern China (Fig. 1). The monthly emissions of $\gamma$-HCH depend on many factors, including temperature and the amount of soil residues of this pesticide. The inventory of $\mathrm{Li}$ et al. (2008) takes these factors into account, using meteorological data for the year 2005. For our study, the 2005 emissions were used also for more recent years.

Annual PCB-28 emission fluxes were taken from an emission inventory created by Breivik et al. (2007) for the years 2004-2007, using the most realistic worst-case scenario (Breivik et al., 2007). This worst case scenario for PCB-28 for the year 2005 is significantly higher than the intermediate scenario, which reflects the very large uncertainties of the actual emission estimates (Breivik et al., 2002b, 2007). For PCB-28 the main emission regions can be found over eastern North America, Europe, western Russia and Japan (Fig. 1), which are the areas where PCBs have been used most extensively in the past (Breivik et al., 2002a, 2007).

The PCB emission inventory does not include seasonal variability. Temperature is a major driving factor driving the seasonal variability but there are other factors as well. For instance, indoor emissions are influenced by building ventilation rates (Currado and Harrad, 1998, 2000) and combustion processes also vary seasonally (Ahling et al., 1978; Kocan et al., 1991) but for both there is no simple temperature relationship. As very little is known about the seasonal variability in primary PCB emissions, a simple linear relationship was assumed which should give higher emissions in summer than in winter.

For deriving a conservative temperature dependence we used the following linear relationship:

$E(m, i)=\overline{E(\iota)} * C(m, i)$

where $E(m, i)$ are the $m$ monthly emission fluxes for every grid cell $i, \overline{E(\iota)}$ is the average monthly mean emission flux, and $C(m, i)$ is a monthly correction factor calculated for every grid cell $i . C(m, i)$ is calculated according to a linear relationship with monthly mean $2 \mathrm{~m}$ air temperature $T(m, i)$ taken from the ECMWF analyses,

$C(m, i)=\frac{T(m, i) * a+b}{\overline{T(\iota)}}$

The slope $a=0.05$ and the intercept $b=-13.5 \mathrm{~K}$ were chosen subjectively in order to represent a reasonable dependence on air temperatures with a maximum in July which is 50\% higher than the annual mean value and a minimum 


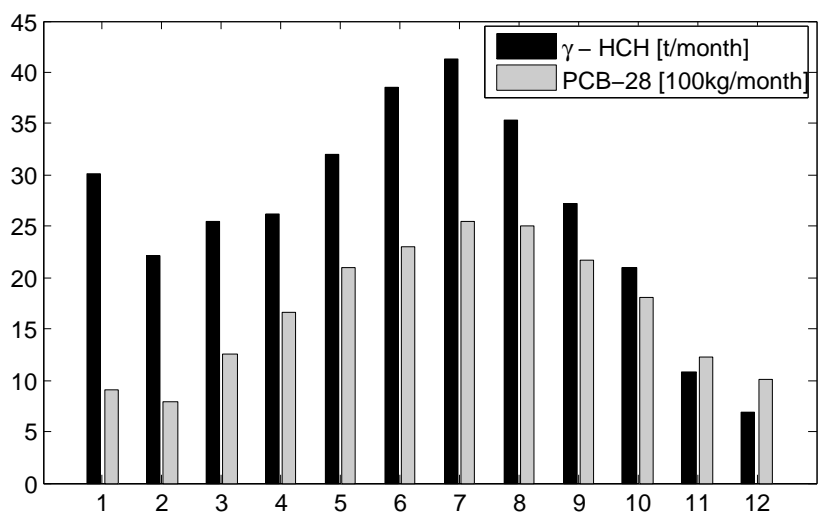

Fig. 2. Monthly average emissions of $\gamma-\mathrm{HCH}$ and PCB-28 integrated over a box over Europe $\left(10^{\circ} \mathrm{W}\right.$ to $50^{\circ} \mathrm{E}$ and north of $\left.20^{\circ} \mathrm{N}\right)$. Note the different units.

which is $50 \%$ lower. In order to preserve the total annual emission $(12 \times \overline{E(\iota)})$ in each grid cell, a normalization with the monthly average temperature $(\overline{T(\iota)})$ of the respective year is needed. In order to avoid negative values, all emissions for temperatures below $264 \mathrm{~K}$ were set to 0 .

Figure 2 shows the monthly emissions of both substances integrated over a box over Europe which is the main source region for the Birkenes station. For PCB-28, the monthly values are averages over the whole 4-year period. $\gamma$-HCH emissions are more than 10 times higher than PCB-28 emissions. For both substances, emissions peak during summertime. For $\gamma-\mathrm{HCH}$, however, the European emissions in January were higher than the emissions in February, March and April (see Fig. 2), mainly because temperatures in Europe were slightly higher in January than in February and March 2005 but also because of decreasing soil concentrations. In other regions emissions increased from January through April (not shown), more in line with what may be expected.

\subsection{Measurements}

We use here weekly measurements from the research station Birkenes in Southern Norway $\left(58^{\circ} 23^{\prime} \mathrm{N}, 8^{\circ} 15^{\prime} \mathrm{E}\right.$, $190 \mathrm{~m}$ a.s.l.) performed during the time period 2004 to 2007. Birkenes is an intensive EMEP monitoring site (e.g. Amundsen et al., 1992; Yttri et al., 2007) mainly surrounded by forest. A lake and a few low intensity agricultural fields are nearby and two small cities (Lillesand, $15 \mathrm{~km}$ to the southeast, population of 9000; Kristiansand, $25 \mathrm{~km}$ to the southsouthwest, population of 79000 ) are in the vicinity. Results from an earlier PCB measurement campaign at this site were reported by Oehme (1991) but a regular POP monitoring program was not initiated until the year 2004.

For sampling, a combination of a glass fiber filter and two polyurethane foam (PUF) plugs $\left(25 \mathrm{~kg} / \mathrm{m}^{3}, 11 \times 5 \mathrm{~cm}\right)$ was used (e.g. Thrane and Mikalsen, 1981). The glass fiber filter was cleaned by heating to $450^{\circ}$ for $8 \mathrm{~h}$. The PUFs were

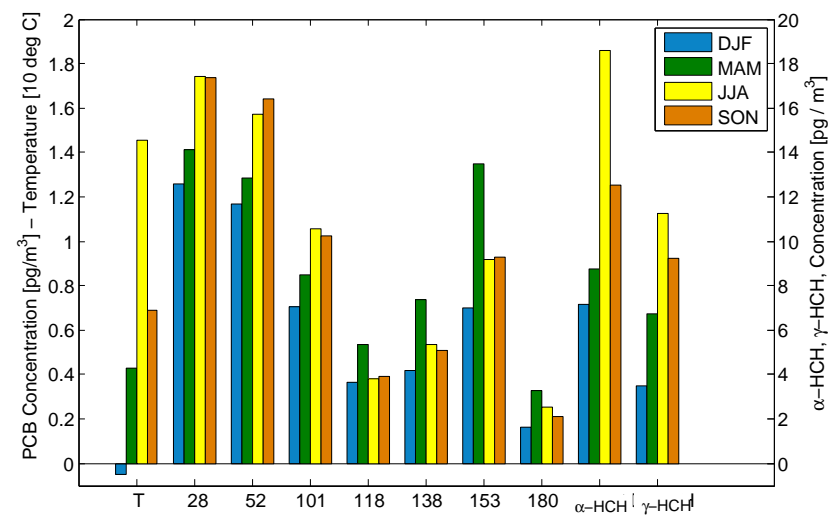

Fig. 3. Temperature $(T)$ and concentrations of seven PCB congeners, $\alpha-\mathrm{HCH}$ and $\gamma-\mathrm{HCH}\left[\mathrm{pg} / \mathrm{m}^{3}\right]$ measured at Birkenes in the period 2004-2007 and averaged over the four seasons DJF (December to February), MAM (March to May), JJA (June to August) and SON (September to November). Note the different scales for PCBs and $\mathrm{HCHs}$.

pre-extracted with acetone and toluene for $8 \mathrm{~h}$ using Soxhlet extraction and then dried under vacuum. For each measurement, a sample volume of about $500 \mathrm{~m}^{3}$ air was taken over a $24 \mathrm{~h}$ period using a high volume sampler. After sampling, the exposed filter and PUFs were sent to the laboratory for analysis. A mix of ${ }^{13} \mathrm{C}$-isotope labeled standards of PCBs was added to filter and PUFs and they were Soxhlet extracted using hexane/diethyl ether 9:1. After pre-concentration to $2 \mathrm{ml}$, concentrated sulphuric acid was added in order to eliminate other non-persistent components. The organic phase was then cleaned using a silica column ( $4 \mathrm{~g}$ silica) eluted with n-hexane/diethyl ether. The sample was further concentrated by applying a gentle stream of purified nitrogen. After volume reduction to approximately $0.1 \mathrm{ml}$, tetrachloronaphthalene was added as a recovery standard. The isomer identification and quantification was done using a HewlettPackard 6890 gas chromatograph coupled to an AutoSpec mass spectrometer (Micromass Waters, Manchester, UK). The high-resolution gas chromatographic conditions were as follows: separation on a $50 \mathrm{~m} \times 0.22 \mathrm{~mm}$ inner diameter fused silica capillary coated with $0.15 \mu \mathrm{m}$ of HT-8; carrier gas, He, at a flow of $35-40 \mathrm{~cm} / \mathrm{s}\left(90^{\circ} \mathrm{C}\right)$ splitless injection of $1 \mu \mathrm{L}$; splitless time $2 \mathrm{~min}$; injector temperature $280^{\circ} \mathrm{C}$; temperature program $90^{\circ} \mathrm{C}$ for $2 \mathrm{~min}$, then $25^{\circ} \mathrm{C} / \mathrm{min}$ to $170^{\circ} \mathrm{C}$, and $3^{\circ} \mathrm{C} / \mathrm{min}$ to $300^{\circ} \mathrm{C}$, finally $3 \mathrm{~min}$ isothermal.

The detection and quantification were done using high resolution mass spectrometry (resolution $>10000$ ) with electron impact ionization. Two masses were monitored for each isomer group. Compounds with certified purity $(\geq 98 \%)$ were used as reference standards. A rigorous quality control concept for the determination of organic compounds in air based on the requirements in the European quality norm NS-EN ISO/IEC 17025 was applied. Before each new series of samples was analyzed, the blank values of the 
Table 1. Number of samples $(N)$, slopes of partial pressure versus reciprocal absolute temperature, correlation coefficient $(R)$, mean concentration and standard deviation of seven PCB congeners [pg m${ }^{-3}$ ], for the years 2004-2007 measured at Birkenes.

\begin{tabular}{llllll}
\hline Subs & $N$ & Slope & $R$ & Mean & Stddev \\
\hline PCB-28 & 144 & -3268.04 & 0.44 & 1.55 & 0.82 \\
PCB-52 & 140 & -3145.74 & 0.41 & 1.43 & 0.79 \\
PCB-101 & 137 & -4326.93 & 0.50 & 0.92 & 0.66 \\
PCB-118 & 133 & -4173.43 & 0.39 & 0.41 & 0.70 \\
PCB-138 & 131 & -4874.98 & 0.46 & 0.54 & 0.95 \\
PCB-153 & 131 & -4866.69 & 0.44 & 0.95 & 1.78 \\
PCB-180 & 133 & -5301.67 & 0.44 & 0.23 & 0.35 \\
\hline
\end{tabular}

complete clean-up and quantification procedures were determined. Clean-up of samples was only started when a sufficiently low blank value was obtained (not detectable or at least 10 times lower than the lowest expected measurement value). Criteria for quantification were: The retention of the ${ }^{12} \mathrm{C}$-labeled compound must not be later than $3 \mathrm{~s}$ compared to the corresponding ${ }^{13} \mathrm{C}$ labeled isomer and the isotope ratio of the two monitored masses must be within $\pm 20 \%$ of the theoretical value. For quantification, the signal/noise ratio must be higher than $3 / 1$ and recovery of the added ${ }^{13} \mathrm{C}$-labeled internal standards must be within 40 to $130 \%$ (trichlor PCBs $20-130 \%)$.

\section{Mean levels and annual variation}

POP measurements at Birkenes started in the year 2004, when the station was moved there from Lista, which is at a distance of $100 \mathrm{~km}$ from Birkenes. Seasonal mean values for the various POPs are shown in Fig. 3. The average PCB concentrations measured at Birkenes $\left(0.9,0.5,0.2 \mathrm{pg} \mathrm{m}^{-3}\right.$ for PCBs 101, 138 and 180, respectively) are significantly lower than those measured at Lista during the years 19921995 (42, 46, $\left.6 \mathrm{pg} \mathrm{m}^{-3}\right)$, which were reported by Haugen et al. (1999). These authors also reported that concentrations in Lista in summer were three times as high as those in winter. Such a strong seasonality cannot be seen in recent data from Birkenes (Fig. 3). However, Haugen et al. (1999) also suspected that the site was under influence of a local source of PCBs (Haugen et al., 1999). Compared to concentrations measured at the Arctic station Zeppelin, Ny Ålesund on Spitsbergen (Eckhardt et al., 2007), the less chlorinated PCB congeners have lower and the higher chlorinated ones higher concentrations at Birkenes. For instance, mean PCB28 (PCB-180) concentrations at Birkenes are 60\% (300\%) of the corresponding values at Zeppelin.

Correlation with the reciprocal temperature explains up to $25 \%$ of the measured concentration variability in Birkenes (Table 1). Highest correlation is seen with PCB-101. The a) Trajectory

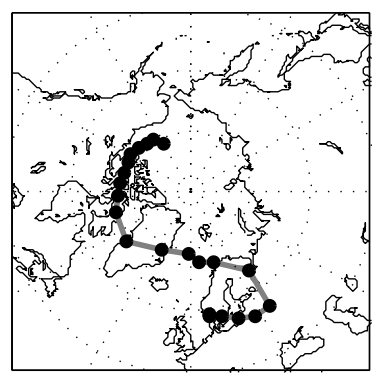

c) ES - PCB-28 [ns]

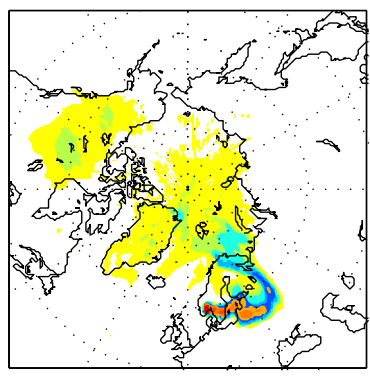

b) ES - Passive Tracer [ns]

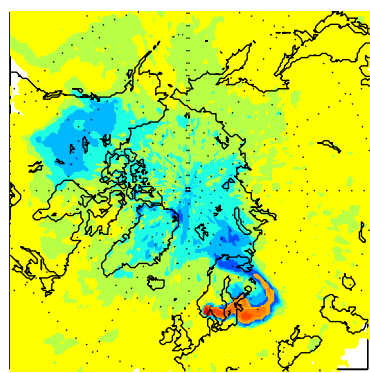

d) $\mathrm{ES}-\gamma-\mathrm{HCH}[\mathrm{ns}]$

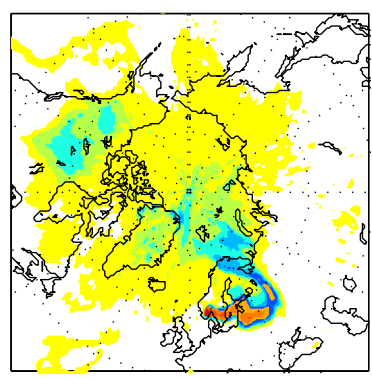

e) EC - PCB-28 [1E12 pg/m5] f) EC $-\gamma-\mathrm{HCH}\left[1 \mathrm{E} 13 \mathrm{pg} / \mathrm{m}^{5}\right]$

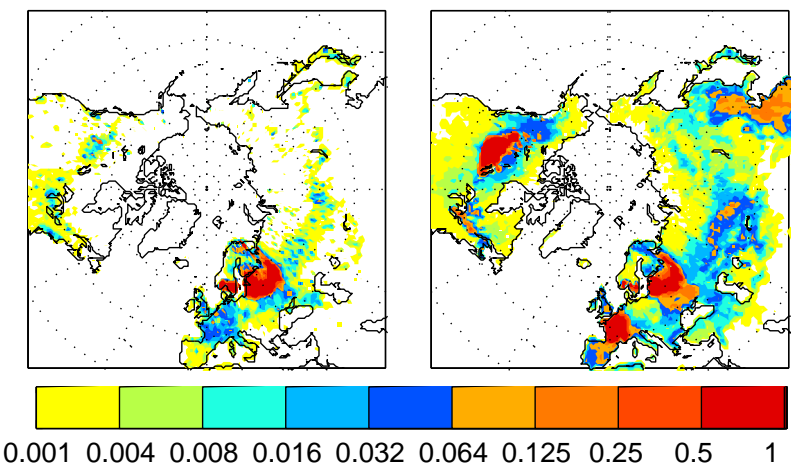

Fig. 4. Model results for the case study of a measurement sample taken at Birkenes from 7-8 June 2007: (a) Mean retroplume trajectory, with the grey line indicating the retroplume mean trajectory and black dots marking daily intervals. (b) emission sensitivities (ES) in the footprint layer for a passive tracer experiencing no removal processes; (c) same as (b) but for simulated PCB-28, and (d) ES for simulated $\gamma-\mathrm{HCH}$. (e) Emission contributions (EC) for simulated PCB-28 and (f) for simulated $\gamma-\mathrm{HCH}$.

slopes increase with the degree of chlorination, in agreement with the findings of Haugen et al. (1999) for Lista. Some studies suggest that the temperature dependence of the concentrations of semivolatile organic compounds can be used to distinguish between evaporation from adjacent soil and long range transport (Wania et al., 1998; Hoff et al., 1998; Gouin et al., 2002). Hung et al. (2001) found that lower chlorinated congener concentrations are mainly driven by atmospheric transport. However, for our station, positive temperature anomalies are correlated with transport from the major 


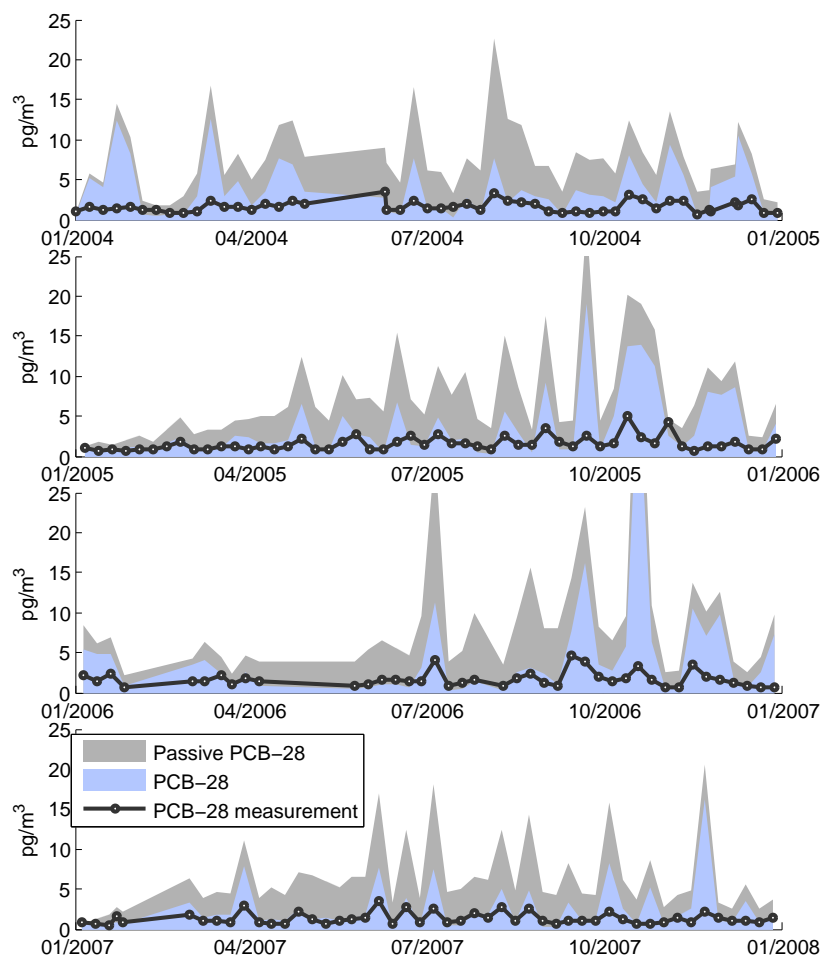

Fig. 5. Time series of modeled and measured PCB-28 $\left[\mathrm{pg} \mathrm{m}^{-3}\right]$. The grey area represents the concentrations of a passive PCB-28 tracer without removal processes, the blue area shows the modeled concentration of PCB-28 including removal processes, the black line with circles shows the measurements in $\mathrm{pg} \mathrm{m}^{-3}$.

European source regions to the south of the station. In fact, as will be shown later, the concentration variability at the station can be explained better by the variability in the contributing source regions than by temperature. Therefore, the temperature dependence cannot be used to distinguish between local and remote sources. At least at Birkenes it is mainly a result of transport.

The concentrations of the less chlorinated PCB congeners (28-101) are higher than those of the more chlorinated PCB congeners (118-180). While the less chlorinated congeners have their highest concentrations in summer and fall, the more chlorinated congeners peak in spring (Fig. 3). The $\mathrm{HCHs}$ show a clear maximum in summer and a minimum in winter. This can partly be explained by the variation of emissions which in Europe are two times higher in summer than in winter (see Fig. 2).

\section{A case study}

In order to explain the method used for simulating the concentrations at Birkenes with the FLEXPART model, we start by presenting a case study. The 24-h sample taken from 7-8 June shows the highest measured PCB-28 $\left(3.6 \mathrm{pg} \mathrm{m}^{-3}\right)$ and

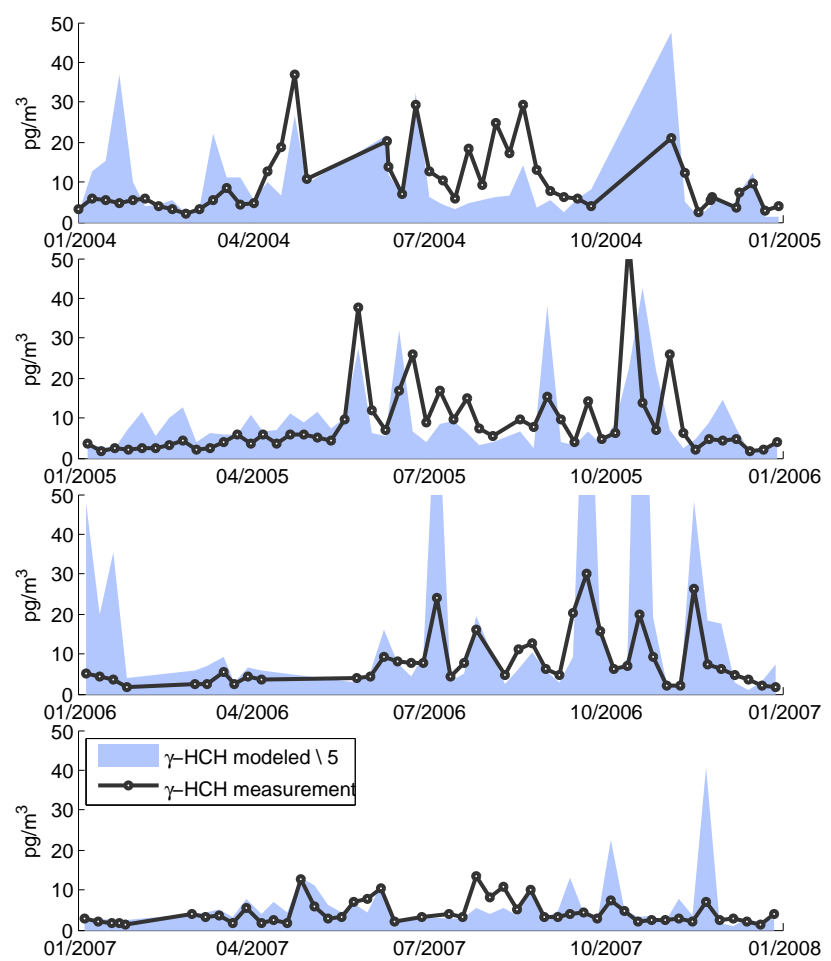

Fig. 6. Time series of modeled $\gamma-\mathrm{HCH}$ (blue) $\left[\mathrm{pg} \mathrm{m}^{-3}\right]$ divided by 5 as well as measured $\gamma-\mathrm{HCH}$ (circles and line).

third highest $\gamma-\mathrm{HCH}\left(10.3 \mathrm{pg} \mathrm{m}^{-3}\right)$ concentration of the year 2007. During the $24 \mathrm{~h}$ of sampling, 40000 particles were released and followed backward for 50 days. For estimating the potential for uptake of emissions, the ES in the footprint layer (0-100 m a.g.l.) is used for further analyses (Fig. 4). The ES units are nanoseconds (ns), which corresponds to a residence time of the air mass. Figure $4 \mathrm{~b}$ shows the footprint ES for a passive tracer, which is not removed by deposition or OH-reaction and $4 \mathrm{c}$ shows the ES for PCB-28. It can be seen that at greater distances from Birkenes (especially over North America) the ES values for the PCB-28 tracer are lower than for the passive tracer. The values around the station (which is located in the boundary layer) are highest, and decrease along the advection pathway as the sampled air mass disperses backward in time and is also mixed to higher altitudes (and as removal processes reduce the ES in the case of PCB-28 and $\gamma-\mathrm{HCH})$. The highest ES values can be found south-east of the station, along a pathway from the Baltic Sea towards western Russia and then towards the Arctic and over western North America. This is where the air mass sampled at Birkenes had the highest potential for uptake of emissions. The plume centroid trajectory (or "mean" trajectory) is also shown in Fig. 4a.

Multiplying the ES (normalized by the area of each grid cell - unit $\left[\mathrm{s} \mathrm{m}^{-2}\right]$ ) with the emission flux from the inventory (which is given in $\mathrm{kg} \mathrm{m}^{-3} \mathrm{~s}^{-1}$ ) and normalizing it by area gives EC in units of $\mathrm{kg} \mathrm{m}^{-5}$. For PCB-28, western Russia 

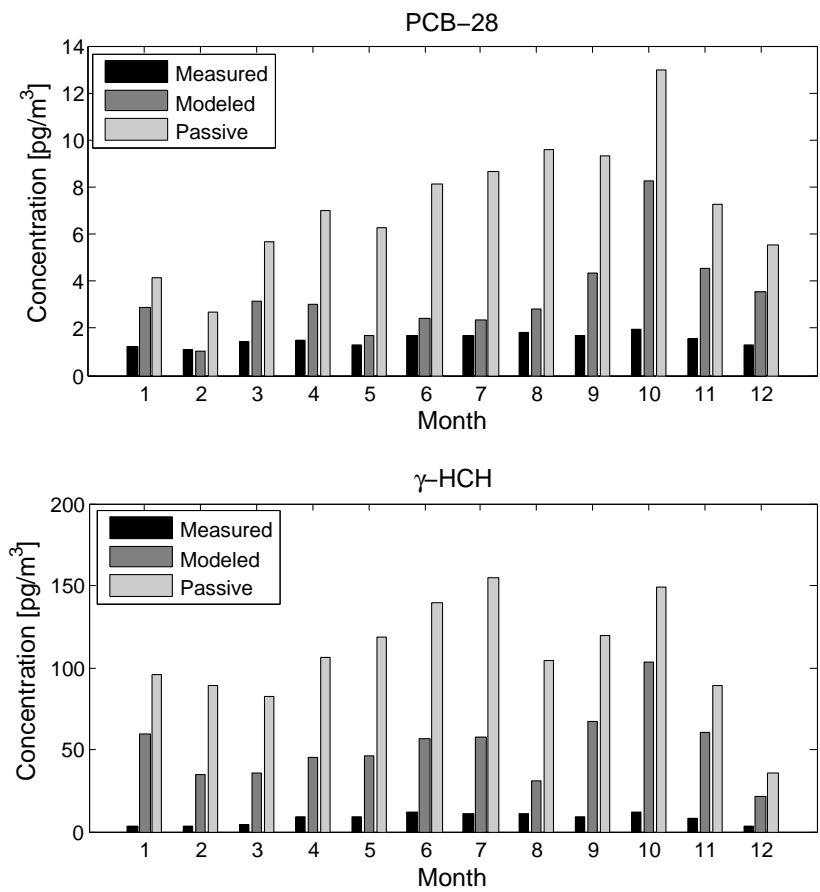

Fig. 7. Seasonal variation of the monthly mean concentrations of PCB-28 (upper panel) and $\gamma-\mathrm{HCH}$ (lower panel). Shown are the measurements (black bars) and the model results (dark grey bars) for PCB-28 and $\gamma$-HCH. Passive PCB-28 and $\gamma-\mathrm{HCH}$ tracers for which removal processes were ignored (light grey bars) are also shown.

is shown to be the main contributing region where both the ES as well as the emission flux are substantial. In southern Scandinavia, the ES is high but the emissions are low, giving a moderate EC. Finally, there is a large region over Europe with modest EC, due to low sensitivity but substantial emission fluxes.

For $\gamma-\mathrm{HCH}$, the ES is intermediate between the passive and the PCB-28 tracer because PCB-28 is much faster removed by $\mathrm{OH}$-reaction than $\gamma-\mathrm{HCH}$. For instance, at a temperature of $25^{\circ} \mathrm{C}$ and an average $\mathrm{OH}$ concentration of $7.25 \times 10^{5} \mathrm{~mol} \mathrm{~cm}^{-3}$ PCB-28 has an e-folding lifetime versus removal by $\mathrm{OH}$ of 15 days, while $\gamma$-HCH has a much longer lifetime of 84 days. The source regions for $\gamma-\mathrm{HCH}$ are similar to those of PCB-28 but there is a large additional EC in a well confined region in Canada where $\gamma-\mathrm{HCH}$ emission fluxes are very large. In this region lindane is applied to corn and canola crops (Li et al., 2004b).

Areal integration of the EC gives a PCB-28 concentration of $7.7 \mathrm{pg} \mathrm{m}^{-3}$ for the receptor location which is in reasonable agreement with the measured PCB-28 concentration of $3.6 \mathrm{pg} \mathrm{m}^{-3}$, given the major uncertainties recognised in the emission data (Breivik et al., 2007). The modeled $\gamma$-HCH of $55.6 \mathrm{~g} \mathrm{~m}^{-3}$, however, overestimates the measured concentration of $10.3 \mathrm{pg} \mathrm{m}^{-3}$ by a factor of 5 .
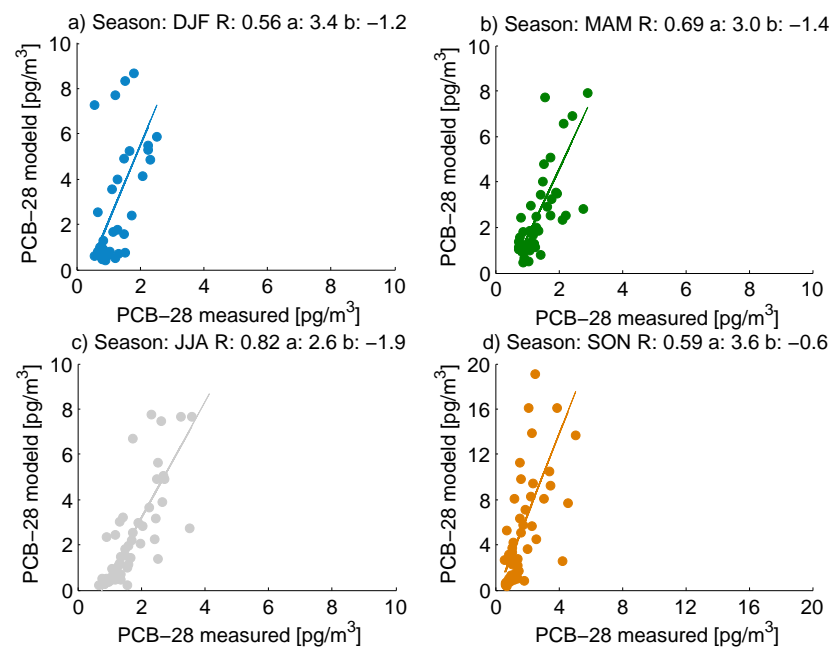

Fig. 8. Correlation between modeled and observed PCB-28 for the four seasons. On top of each panel, correlation coefficient $R$, slope $a$ and intercept $b$ are reported.

With the 50-day length of the model calculations, we ignore emission contributions from times earlier than 50 days before the measurement was taken. To justify this cut-off, we calculated for the year 2006 the contribution of tracer aged between 45 and 50 days, which is only $0.4 \%$ for PCB-28 and $1.8 \%$ for $\gamma-\mathrm{HCH}$ respectively. This shows that the duration of the backward simulation is sufficiently long to capture most of the contributing emissions.

\section{Statistical analyses of the model output}

In this section the modeled values are compared statistically with the measured values. For PCB-28 (Fig. 5), predicted and observed concentrations are of comparable magnitude, and many of the elevated measured concentrations are captured well by the model. Especially from April 2006 onwards the timing of most enhancements could be well reproduced both by the passive PCB-28 tracer (without removal) as well as by modeled PCB-28 (with removal). Removal processes are important, since modeled PCB-28 concentrations are just $40 \%$ of the PCB-28 passive tracer concentrations. Especially in the cold seasons the concentrations are nevertheless clearly overestimated even when removal processes are accounted for. Given the uncertainties in the emission inventory and the fact that we have chosen the highest emission scenario (see Sect. 2), the agreement between the model and the measurement data is encouraging.

Figure 6 shows the comparison between modeled and measured $\gamma-\mathrm{HCH}$. As the median of the modelled $\gamma-\mathrm{HCH}$ concentration is overestimating the median of the measured concentrations by a factor of 5.4, the modeled values are divided by a factor of five for plotting purposes. Again, there is relatively good agreement in the timing of pollution events 

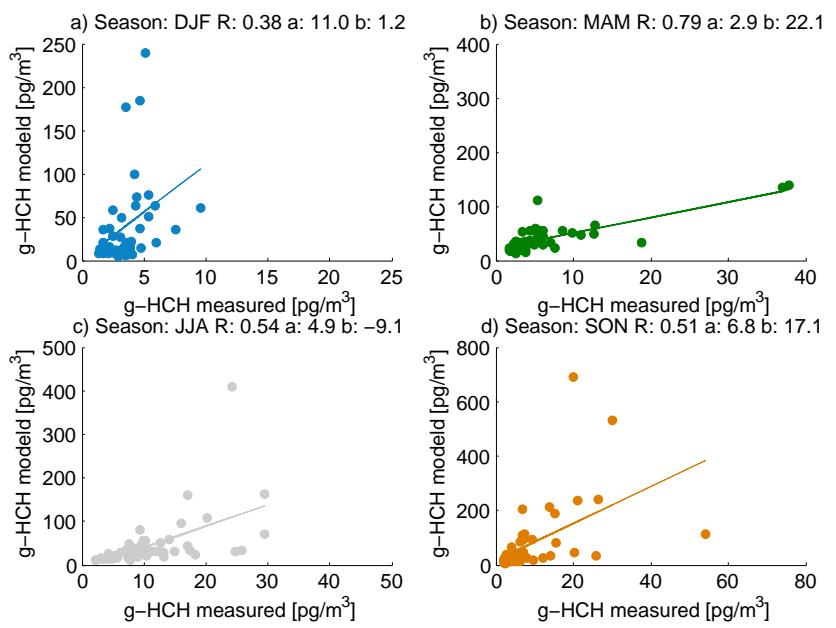

Fig. 9. Same as Fig. 8 but for $\gamma-\mathrm{HCH}$. Notice that the scale on the ordinate extends to ten times larger values than the scale on the abscissa.

but the concentration overestimation by the model is substantial.

To compare modeled with measured values on a quantitative basis, we established a monthly climatology of the average measured PCB-28, average modeled PCB-28 and average modeled passive PCB-28 (Fig. 7, upper panel). From May to August there is very good agreement between the modeled and measured concentration levels, with only a slight overestimation. In winter, the model overestimates more strongly. Notice also that modeled PCB- 28 concentrations in summer and winter are $24 \%$ and $52 \%$, respectively of the passive tracer, reflecting the seasonal change in removal process and, thus, atmospheric lifetime of PCB-28.

As the agreement between model and measurement varies throughout the year, we performed correlation analyses separately for the four three-monthly periods MAM, JJA, SON and DJF (Fig. 8). For these seasons 44, 43, 52 and 53 samples were available, respectively. All correlations have a significance level greater than $0.1 \%(p<0.001)$. For PCB-28 the best fit is observed in summer, where a correlation coefficient $(R)$ of 0.8 is found and the slope is 2.6, which shows that the model overestimates the concentrations even in summer. The worst fit is seen for winter, for which $R$ is only 0.56 . In fall, the concentrations are most strongly overestimated by the model, with a slope of 3.6. In summary, while FLEXPART reproduces well the timing of measured concentration variations and, thus, measurements and model values are well correlated, the model systematically overpredicts the concentrations. The most likely explanation for the latter discrepancy is that the emissions are too high, especially in fall and winter.

For $\gamma-\mathrm{HCH}$ the model overestimates the concentrations even more than for PCB-28 (Fig. 7, lower panel). Comparing the passive $\gamma-\mathrm{HCH}$ tracer and $\gamma-\mathrm{HCH}$, which is also subject
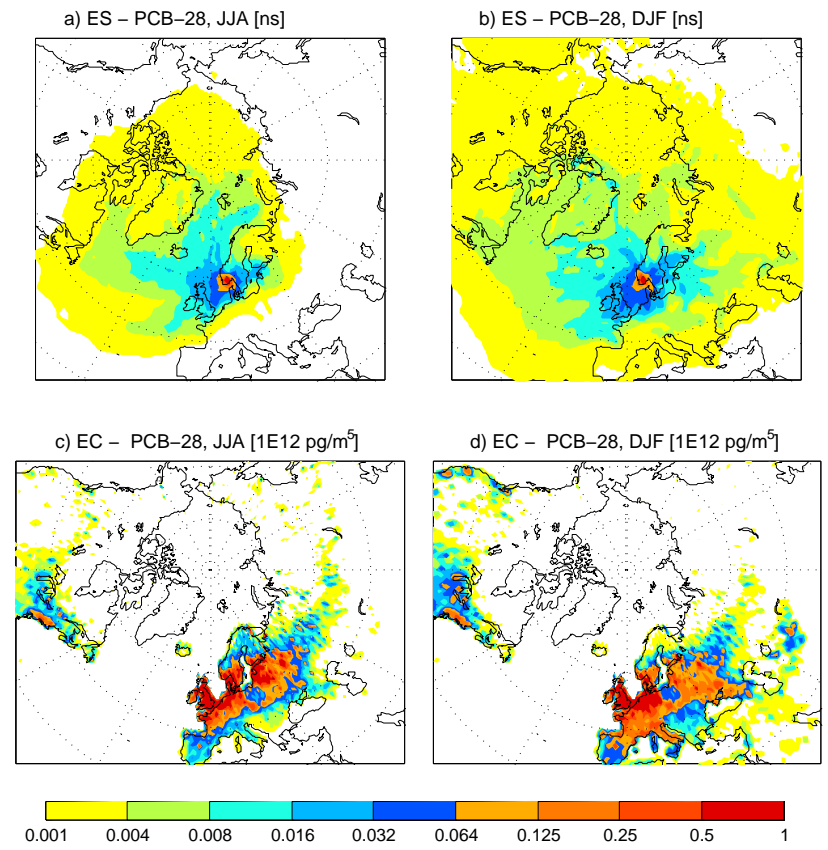

Fig. 10. Footprint ES maps [ns] (a, b) and EC maps (c, d) for PCB28 averaged over all calculations for summer $(a, c)$ and winter $(b$, d) for the years 2004 to 2007 .

to removal processes it can be seen, that in summer $60 \%$ and in winter $50 \%$ of the passive tracer is removed. Correlations between model and measurement (Fig. 9) reveal the best fit for spring, for which $R$ is 0.79 . In winter the results are most strongly overpredicted with a slope of 11 .

At the same time, the good correlations between model and measurements (Figs. 8, 9) suggest that the spatial patterns in both emission inventories are relatively well captured. This is because the major usage areas of PCBs and $\gamma-\mathrm{HCH}$ are better known than the actual emissions strength. This, in turn, suggests that the model may be a useful tool to identify and evaluate key source regions as discussed in the following

\section{Source regions}

As for the case study, ES and EC maps were produced for all samples taken during the four years. By averaging over all cases during the four years, we can see which regions contributed to the modeled PCB-28 and $\gamma-\mathrm{HCH}$ concentrations (Figs. 10, 11). The maximum ES values are, of course, found in the vicinity of the measurement station and decrease with distance from the station. The decrease with distance is stronger for summer than for winter, due to both slower transport and more efficient removal in summer than in winter. Especially the European continent has less influence in summer than in winter. This implies that sources far away from the measurement station have a greater chance of contributing to 

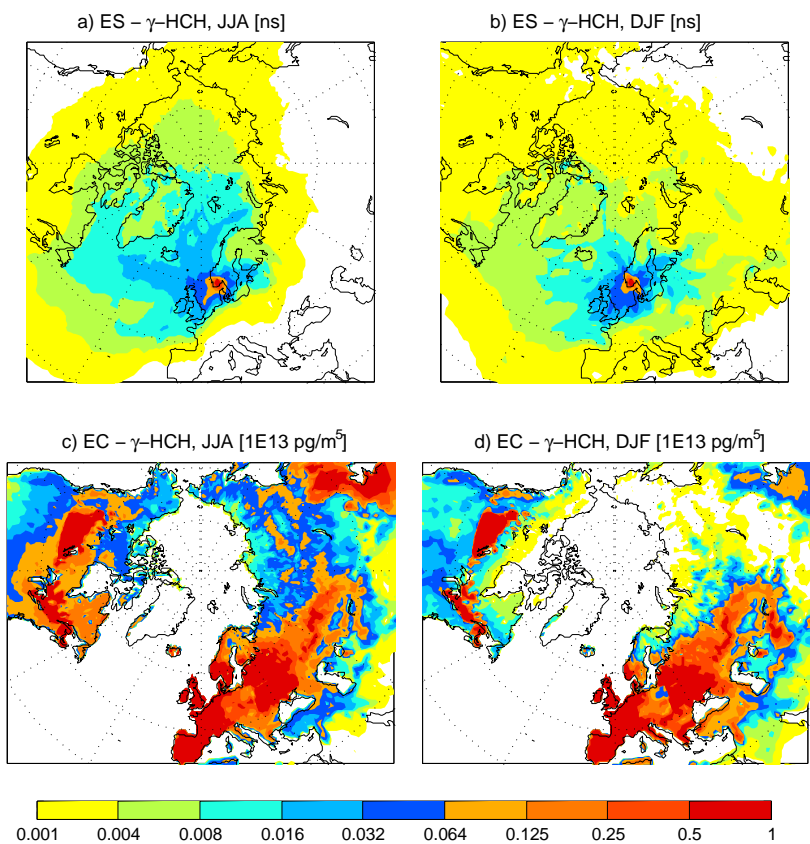

Fig. 11. Same as Fig. 12 but for $\gamma-\mathrm{HCH}$.

the concentrations at Birkenes in winter. This is seen in the EC maps for PCB-28 (Fig. 10c, d). While Northwestern Europe is a significant PCB-28 source for Birkenes both in summer and in winter, sources in southern Europe are important only in winter. Furthermore, intercontinental transport from North America is more important in winter than in summer, despite the higher summer-time emissions.

For $\gamma-\mathrm{HCH}$ the ES is similar, but due to less effective removal processes the ES values decrease slower with distance to the station compared to PCB-28. The contributing sources can be found over wide areas of Europe. Due to high emissions in Canada, the influence of the Canadian prairies can be seen clearly.

A good way to summarize the EC is to integrate the EC values over selected regions, as shown by the color codes in Fig. 12. Of these regions, Central Europe contributes the most for PCB-28 (32\%). 24\% of the simulated average concentration can be attributed to Eastern Europe and $15 \%$ to the UK, a small fraction (4\%) came from America . For $\gamma$ $\mathrm{HCH}$, Western Europe is clearly the main contributor for the Birkenes station, accounting for more than $50 \%$ of the $\gamma$ $\mathrm{HCH}$ burden. Due to relatively higher emissions than for PCB-28, the North American contribution is around $12 \%$.

As the agreement between the model and the measurements is not perfect, a correction was applied by normalizing each EC map with the ratio between measured and modeled concentrations (see Fig. 12, grey bars). For both substances, this reduces the relative contributions from Central Europe and Western Europe and increases the relative contributions from other regions, especially from North America.
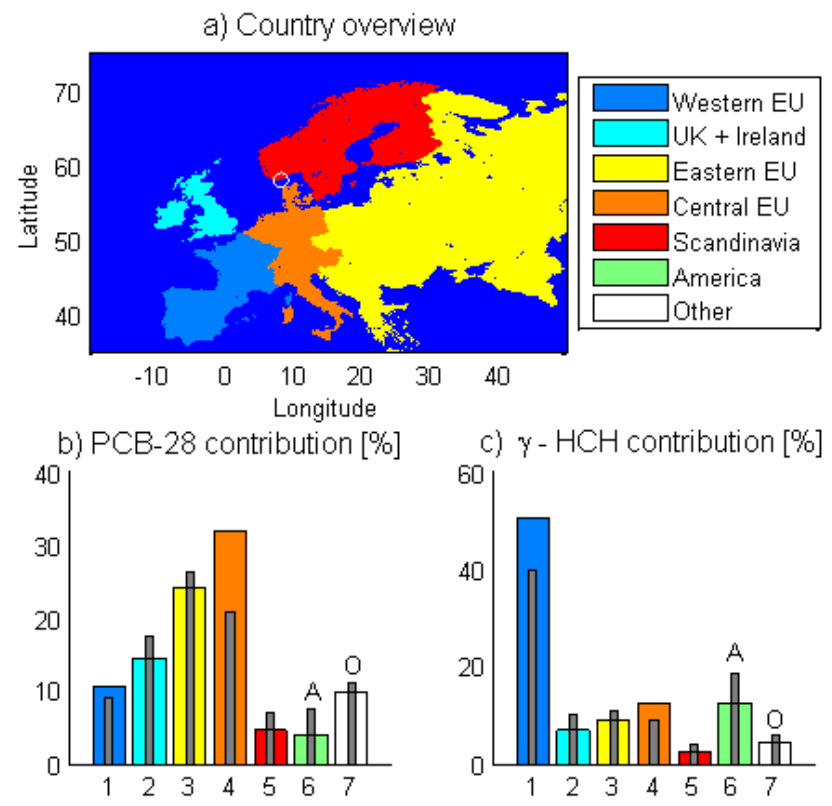

Fig. 12. Panel (a) shows the different regions for which relative source contributions for the Birkenes station (marked with a white circle) have been calculated (1, Western Europe ; 2, UK and Ireland; 3, Eastern Europe; 4, Central Europe; 5, Scandinavia; 6, America (denoted with A); 7, other countries (denoted with O)) Panels (b) and (c) show the regional source contributions (in $\%$ of the total) for simulated PCB-28 and $\gamma-\mathrm{HCH}$, respectively, with the colors indicating the contributions from the different regions as colored in panel (a). The grey bars show the contributions when they are weighted by the ratio of the measured/modeled concentrations.

This suggests that the emissions in Central and Western Europe are overestimated even more strongly than the globally averaged emissions.

\section{Conclusions}

We have presented a new 4-year (2004-2007) data set of weekly measurements of PCBs and HCHs from the EMEP station Birkenes in southern Norway. The average concentrations of PCB-28, PCB-101, PCB-180, $\alpha-\mathrm{HCH}$ and $\gamma-\mathrm{HCH}$ were $1.5,0.9,0.2,12$ and $7.8 \mathrm{pg} \mathrm{m}^{-3}$, respectively. Concentrations of the less chlorinated PCB congeners 28 to 101 were highest in summer and fall, whereas the more chlorinated congeners 118 and 180 peaked in spring. Concentrations of $\alpha-\mathrm{HCH}$ and $\gamma-\mathrm{HCH}$ were highest in summer. Air temperature is a relatively poor predictor of $\mathrm{PCB}$ concentrations, explaining from $15 \%$ (for PCB-118) to $25 \%$ (for PCB$101)$ of the observed PCB concentration variability. Variability in transport explains a much larger fraction of the variability in observed concentrations. We conclude that at Birkenes the observed correlation between temperature and $\mathrm{PCB}$ and $\mathrm{HCH}$ concentrations is primarily a consequence of long-range transport from cold and clean regions and from 
warm and polluted regions. Temperature correlation, thus, cannot be used to distinguish between evaporation from adjacent soil and long range transport as suggested by some authors (Wania et al., 1998; Hoff et al., 1998; Gouin et al., 2002).

We have used a Lagrangian particle dispersion model, FLEXPART, in adjoint (backward) mode to simulate the atmospheric transport of POPs to the Birkenes station. At present, the model is most suitable for POPs that occur predominantly in the gaseous state in the atmosphere (e.g., $\gamma$ $\mathrm{HCH}$ or the lower chlorinated PCBs) and the atmospheric concentrations of which are controlled by primary sources.

We found that the model successfully explains a large fraction of the variability in the measurement data. For instance, $31,47,67$, and $34 \%$ of the variance of the PCB-28 $(14,62$, 29 and $26 \%$ of the variance of the $\gamma-\mathrm{HCH}$ ) measurement data are explained by the model simulations in winter, spring, summer and fall, respectively. For PCB-28, the model shows a moderate bias in summer (24\%) but overpredicts PCB-28 concentrations in winter by a factor 2 . For $\gamma-\mathrm{HCH}$, the model strongly overpredicts throughout the year, on average by a factor of 8. The reasons for the model overpredictions are not entirely clear. However, the uncertainties in both emission inventories are very large. For instance, for PCB-28 we have chosen the "high" scenario of Breivik et al. (2007) since we considered this scenario as the most realistic. The strong overprediction of $\gamma-\mathrm{HCH}$ could be attributed to the emissions or point towards an underestimation of the removal of $\gamma$-HCH in our model.

We have used the model to estimate the emission contributions from different regions to the PCB-28 and $\gamma-\mathrm{HCH}$ concentrations at Birkenes. We found that for $\gamma-\mathrm{HCH}$ the main source region is Western Europe, which contributes half of the concentrations measured at this station. Central Europe and America both contribute approximately $10 \%$. For PCB-28 source contributions are more evenly distributed over Eastern, Central Europe and UK and Ireland, which together contribute $70 \%$ of the total burden.

By comparing measured and modelled values, we find that for both PCB-28 and $\gamma-\mathrm{HCH}$ the model overestimates most strongly when the air arrives from Central and Western Europe, suggesting that particularly the emissions in these regions are overestimated in the inventories used.

In summary, the FLEXPART model in adjoint mode has been found to be a useful tool to evaluate source-receptor relationships for PCB-28 and $\gamma-\mathrm{HCH}$. It could also be used for other POPs that occur predominantly in the gaseous state. In the future, based on the FLEXPART output an inversion algorithm such as presented by Stohl et al. (2009) could be used to improve the a priori emission inventories.
Acknowledgements. This study was part of the FLEXPOP project funded by the Research Council of Norway (project 171574/S30). We thank SFT and EMEP for funding the monitoring at Birkenes. I. Bey has provided the $\mathrm{OH}$ fields and ECMWF and the Norwegian MetOffice have given us access to the ECMWF data.

Edited by: A. S. H. Prevot

\section{References}

Ahling, B. and Lindskog, A.: Thermal destruction of PCB and hexachlorobenzene, Sci. Total Environ., 10, 51-59, 1978.

AMAP, A. M. A. P.: Amap assessment 1998: Arctic pollution issues, Oslo, Norway, xii+859 pp., 1998.

ECMWF, E. C. f. M.-R. W. F.: User guide to ECMWF products 2.1, Meteorol. Bull., Reading, England, UK, 1995.

Amundsen, C. E., Hanssen, J. E., Semb, A., and Steinnes, E.: Longrange atmospheric transport of trace-elements to southern Norway, Atmos. Environ. A-Gen., 26, 1309-1324, 1992.

Anderson, P. N. and Hites, R. A.: OH radical reactions: The major removal pathway for polychlorinated biphenyls from the atmosphere, Environ. Sci. Technol., 30, 1756-1763, 1996.

Bey, I., Jacob, D. J., Yantosca, R. M., Logan, J. A., Field, B. D., Fiore, A. M., Li, Q. B., Liu, H. G. Y., Mickley, L. J., and Schultz, M. G.: Global modeling of tropospheric chemistry with assimilated meteorology: Model description and evaluation, J. Geophys. Res.-Atmos., 106, 23073-23095, 2001.

Breivik, K., Pacyna, J. M., and Munch, J.: Use of alpha-, beta- and gamma-hexachlorocyclohexane in Europe, 1970-1996, Sci. Total Environ., 239, 151-163, 1999.

Breivik, K., Sweetman, A., Pacyna, J. M., and Jones, K. C.: Towards a global historical emission inventory for selected $\mathrm{PCB}$ congeners - a mass balance approach 1. Global production and consumption, Sci. Total Environ., 290, 181-198, 2002a.

Breivik, K., Sweetman, A., Pacyna, J. M., and Jones, K. C.: Towards a global historical emission inventory for selected $\mathrm{PCB}$ congeners - a mass balance approach 2. Emissions, Sci. Total Environ., 290, 199-224, 2002b.

Breivik, K., Sweetman, A., Pacyna, J. M., and Jones, K. C.: Towards a global historical emission inventory for selected PCB congeners - a mass balance approach 3. An update, Sci. Total Environ., 377, 296-307, doi:10.1016/j.scitotenv.2007.02.026, 2007.

Brubaker, W. W. and Hites, R. A.: OH reaction kinetics of gas-phase alpha- and gamma-hexachlorocyclohexane and hexachlorobenzene, Environ. Sci. Technol., 32, 766-769, 1998.

Cousins, I. T., Mackay, D., and Jones, K. C.: Measuring and modelling the vertical distribution of semivolatile organic compounds in soils. II: Model development, Chemosphere, 39, 2519-2534, 1999.

Currado, G. M. and Harrad, S.: Comparison of Polychlorinated Biphenyl concentrations in indoor and outdoor air and the potential significance of inhalation as a human exposure pathway, Environ. Sci. Technol., 32, 3043-3047, 1998.

Currado, G. M. and Harrad, S.: Factors influencing atmospheric concentrations of polychlorinated biphenyls in Birmingham, UK, Environ. Sci. Technol., 34, 78-82, 2000.

Du, S. Y. and Rodenburg, L. A.: Source identification of atmospheric PCBs in Philadelphia/Camden using posi- 
tive matrix factorization followed by the potential source contribution function, Atmos. Environ., 41, 8596-8608, doi:10.1016/j.atmosenv.2007.07.042, 2007.

Eckhardt, S., Stohl, A., Beirle, S., Spichtinger, N., James, P., Forster, C., Junker, C., Wagner, T., Platt, U., and Jennings, S. G.: The North Atlantic Oscillation controls air pollution transport to the Arctic, Atmos. Chem. Phys., 3, 1769-1778, 2003, http://www.atmos-chem-phys.net/3/1769/2003/.

Eckhardt, S., Breivik, K., Manø, S., and Stohl, A.: Record high peaks in PCB concentrations in the Arctic atmosphere due to long-range transport of biomass burning emissions, Atmos. Chem. Phys., 7, 4527-4536, 2007, http://www.atmos-chem-phys.net/7/4527/2007/.

Emanuel, K. A. and Živković-Rothman, M.: Development and evaluation of a convection scheme for use in climate models, J. Atmos. Sci., 56, 1766-1782, 1999.

Forster, C., Stohl, A., and Seibert, P.: Parameterization of convective transport in a Lagrangian particle dispersion model and its evaluation, J. Appl. Meteorol. Clim., 46, 403-422, doi:10.1175/jam2470.1, 2007.

Gong, S. L., Huang, P., Zhao, T. L., Sahsuvar, L., Barrie, L. A., Kaminski, J. W., Li, Y. F., and Niu, T.: GEM/POPs: a global 3-D dynamic model for semi-volatile persistent organic pollutants Part 1: Model description and evaluations of air concentrations, Atmos. Chem. Phys., 7, 4001-4013, 2007,

http://www.atmos-chem-phys.net/7/4001/2007/.

Gouin, T., Thomas, G. O., Cousins, I., Barber, J., Mackay, D., and Jones, K. C.: Air-surface exchange of polybrominated biphenyl ethers and polychlorinated biphenyls, Environ. Sci. Technol., 36, 1426-1434, doi:10.1021/es011105k, 2002.

Hafner, W. D. and Hites, R. A.: Potential sources of pesticides, PCBs, and PAHs to the atmosphere of the Great Lakes, Environ. Sci. Technol., 37, 3764-3773, doi:10.1021/es034021f, 2003.

Halsall, C. J.: Investigating the occurrence of persistent organic pollutants (pops) in the Arctic: Their atmospheric behaviour and interaction with the seasonal snow pack, Environ. Pollut., 128, 163-175, doi:10.1016/j.envpol.2003.08.026, 2004.

Hansen, K. M., Christensen, J. H., Brandt, J., Frohn, L. M., and Geels, C.: Modelling atmospheric transport of $\alpha$ hexachlorocyclohexane in the Northern Hemispherewith a 3-D dynamical model: DEHM-POP, Atmos. Chem. Phys., 4, 11251137,2004

http://www.atmos-chem-phys.net/4/1125/2004/.

Hansen, K. M., Prevedouros, K., Sweetman, A. J., Jones, K. C., and Christensen, J. H.: A process-oriented intercomparison of a box model and an atmospheric chemistry transport model: Insights into model structure using alpha-HCH as the modelled substance, Atmos. Environ., 40, 2089-2104, doi:10.1016/j.atmosenv.2005.11.050, 2006.

Harner, T., Shoeib, M., Kozma, M., Gobas, F., and Li, S. M.: Hexachlorocyclohexanes and endosulfans in urban, rural, and high altitude air samples in the fraser valley, british columbia: Evidence for trans-pacific transport, Environ. Sci. Technol., 39, 724 731, doi:10.1029/2004jd004286, 2005.

Harrad, S. J., Sewart, A. P., Alcock, R., Boumphrey, R., Burnett, V., Duartedavidson, R., Halsall, C., Sanders, G., Waterhouse, K., Wild, S. R., and Jones, K. C.: Polychlorinated-biphenyls (PCBs) in the british environment - sinks, sources and temporal trends, Environ. Pollut., 85, 131-146, 1994.
Haugen, J. E., Wania, F., and Lei, Y. D.: Polychlorinated biphenyls in the atmosphere of southern norway, Environ. Sci. Technol., 33, 2340-2345, 1999.

Hertel, O., Christensen, J., Runge, E. H., Asman, W. A. H., Berkowicz, R., Hovmand, M. F., and Hov, O.: Development and testing of a new variable scale air-pollution model - ACDEP, Atmos. Environ., 29, 1267-1290, 1995.

Hoff, R. M., Brice, K. A., and Halsall, C. J.: Nonlinearity in the slopes of Clausius-Clapeyron plots for SVOCs, Environ. Sci. Technol., 32, 1793-1798, 1998.

Huang, P., Gong, S. L., Zhao, T. L., Neary, L., and Barrie, L. A.: GEM/POPs: a global 3-D dynamic model for semi-volatile persistent organic pollutants - Part 2: Global transports and budgets of PCBs, Atmos. Chem. Phys., 7, 4015-4025, 2007,

http://www.atmos-chem-phys.net/7/4015/2007/.

Hung, H., Halsall, C. J., Blanchard, P., Li, H. H., Fellin, P., Stern, G., and Rosenberg, B.: Are PCBs in the Canadian Arctic atmosphere declining? Evidence from 5 years of monitoring, Environ. Sci. Technol., 35, 1303-1311, 2001.

Hung, H., Lee, S. C., Wania, F., Blanchard, P., and Brice, K.: Measuring and simulating atmospheric concentration trends of polychlorinated biphenyls in the northern hemisphere, Atmos. Environ., 39, 6502-6512, doi:10.1016/j.atmosenv.2005.07.012, 2005.

Jamshidi, A., Hunter, S., Hazrati, S., and Harrad, S.: Concentrations and chiral signatures of polychlorinated biphenyls in outdoor and indoor air and soil in a major UK conurbation, Environ. Sci. Technol., 41, 2153-2158, doi:10.1021/es062218c, 2007.

Kocan, A., Petrik, J., Chovancova, J., Neubauerova, L., and Bezacinsky, M.: Pcdd, pcdf and pcb levels in stack emissions from czechoslovak waste burning facilities, ISI:A1991HB10400050, 1473-1480, 1991.

Li, N. Q., Wania, F., Lei, Y. D., and Daly, G. L.: A comprehensive and critical compilation, evaluation, and selection of physicalchemical property data for selected polychlorinated biphenyls, J. Phys. Chem. Ref. Data, 32, 1545-1590, doi:10.1063/1.1562632, 2003a.

Li, Y. F., McMillan, A., and Scholtz, M. T.: Global HCH usage with 1 degrees $\mathrm{x} 1$ degrees longitude/latitude resolution, Environ. Sci. Technol., 30, 3525-3533, 1996.

Li, Y. F., Bidleman, T. F., Barrie, L. A., and McConnell, L. L.: Global hexachlorocyclohexane use trends and their impact on the Arctic atmospheric environment, Geophys. Res. Lett., 25, 39-41, 1998a.

Li, Y. F., Cai, D. J., and Singh, A.: Technical hexachlorocyclohexane use trends in China and their impact on the environment, Arch. Environ. Con. Tox., 35, 688-697, 1998b.

Li, Y. F.: Global technical hexachlorocyclohexane usage and its contamination consequences in the environment: From 1948 to 1997, Sci. Total Environ., 232, 121-158, 1999a.

Li, Y. F.: Global gridded technical hexachlorocyclohexane usage inventories using a global cropland as a surrogate, J. Geophys. Res.-Atmos., 104, 23785-23797, 1999b.

Li, Y. F., Scholtz, M. T., and van Heyst, B. J.: Global gridded emission inventories of alpha-hexachlorocyclohexane, J. Geophys. Res.-Atmos., 105, 6621-6632, 2000.

Li, Y. F., Cai, D. J., Shan, Z. J., and Zhu, Z. L.: Gridded usage inventories of technical hexachlorocyclohexane and lindane for china with 1/6 degrees latitude by 1/4 degrees longitude resolution, Arch. Environ. Con. Tox., 41, 261-266, 2001. 
Li, Y. F., Scholtz, M. T., and Van Heyst, B. J.: Global gridded emission inventories of 6-hexachlorocyclohexane, Environ. Sci. Technol., 37, 3493-3498, doi:10.1021/es034157d, 2003 b.

Li, Y. F., Struger, J., Waite, D., and Ma, J.: Gridded Canadian lindane usage inventories with 1/6 degrees x 1/4 degrees latitude and longitude resolution, Atmos. Environ., 38, 1117-1121, doi:10.1016/j.atmosenv.2003.11.022, 2004.

Li, Y. F., Ren, N. Q., and Tian, C.: China-North America project on reduction of lindane usage in china and its impact globally and on North America, in: Report to North America Commission for Environmental Cooperation (CEC), Environment Canada and US EPA, 2008.

Lohmann, R., Breivik, K., Dachs, J., and Muir, D.: Global fate of pops: Current and future research directions, Environ. Pollut., 150, 150-165, doi:10.1016/j.envpol.2007.06.051, 2007.

Ma, J. M., Daggupaty, S., Harner, T., and Li, Y. F.: Impacts of lindane usage in the Canadian prairies on the great lakes ecosystem. 1. Coupled atmospheric transport model and modeled concentrations in air and soil, Environ. Sci. Technol., 37, 3774-3781, doi:10.1021/es034160x, 2003.

Ma, J. M., Venkatesh, S., Li, Y. F., Cao, Z. H., and Daggupaty, S.: Tracking toxaphene in the North American great lakes basin. 2. A strong episodic long-range transport event, Environ. Sci. Technol., 39, 8132-8141, doi:10.1021/es050946e, 2005.

Mackay, D.: Multimedia environmental models. The fugacity approach 2nd ed, in: Lewis Publishers, Boca Raton, FL, 2001.

Mackay, D. and Reid, L.: Local and distant residence times of contaminants in multi-compartment models. Part I: A review of the theoretical basis, Environ. Pollut., 156, 1196-1203, doi:10.1016/j.envpol.2008.04.012, 2008.

MacLeod, M., Riley, W. J., and McKone, T. E.: Assessing the influence of climate variability on atmospheric concentrations of polychlorinated biphenyls using a global-scale mass balance model (BETR-global), Environ. Sci. Technol., 39, 6749-6756, doi:10.1021/es048426r, 2005.

Malanichev, A., Mantseva, E., Shatalov, V., Strukov, B., and Vulykh, N.: Numerical evaluation of the PCBs transport over the northern hemisphere, Environ. Pollut., 128, 279-289, doi:10.1016/j.envpol.2003.08.040, 2004.

Meyer, T., Wania, F., and Breivik, K.: Illustrating sensitivity and uncertainty in environmental fate models using partitioning maps, Environ. Sci. Technol., 39, 3186-3196, doi:10.1021/es048728t, 2005.

Oehme, M.: Further evidence for long-range air transport of polychlorinated aromates and pesticides - North-America and Eurasia to the Arctic, Ambio, 20, 293-297, 1991.

Sahsuvar, L., Helm, P. A., Jantunen, L. M., and Bidleman, T. F.: Henry's law constants for alpha-, beta-, and gammahexachlorocyclohexanes $(\mathrm{HCHs})$ as a function of temperature and revised estimates of gas exchange in Arctic regions, Atmos. Environ., 37, 983-992, doi:10.1016/s1352-2310(02)009366, 2003.

Seibert, P. and Frank, A.: Source-receptor matrix calculation with a Lagrangian particle dispersion model in backward mode, Atmos. Chem. Phys., 4, 51-63, 2004, http://www.atmos-chem-phys.net/4/51/2004/.

Semeena, V. S. and Lammel, G.: The significance of the grasshopper effect on the atmospheric distribution of persistent organic substances, Geophys. Res. Lett., 32, L07804,
doi:10.1029/2004GL022229, 2005.

Stohl, A., Hittenberger, M., and Wotawa, G.: Validation of the Lagrangian particle dispersion model FLEXPART against largescale tracer experiment data, Atmos. Environ., 32, 4245-4264, 1998.

Stohl, A. and Thomson, D. J.: A density correction for Lagrangian particle dispersion models, Bound.-Lay. Meteorol., 90, 155-167, 1999.

Stohl, A., Forster, C., Eckhardt, S., Spichtinger, N., Huntrieser, H., Heland, J., Schlager, H., Wilhelm, S., Arnold, F., and Cooper, O.: A backward modeling study of intercontinental pollution transport using aircraft measurements, J. Geophys. Res.-Atmos., 108, 4370, doi:10.1029/2002jd002862, 2003.

Stohl, A., Forster, C., Frank, A., Seibert, P., and Wotawa, G.: Technical note: The Lagrangian particle dispersion model FLEXPART version 6.2, Atmos. Chem. Phys., 5, 2461-2474, 2005, http://www.atmos-chem-phys.net/5/2461/2005/.

Stohl, A., Andrews, E., Burkhart, J. F., Forster, C., Herber, A., Hoch, S. W., Kowal, D., Lunder, C., Mefford, T., Ogren, J. A., Sharma, S., Spichtinger, N., Stebel, K., Stone, R., Strom, J., Torseth, K., Wehrli, C., and Yttri, K. E.: Pan-Arctic enhancements of light absorbing aerosol concentrations due to North American boreal forest fires during summer 2004, J. Geophys Res.-Atmos., 111, D22214, doi:10.1029/2006jd007216, 2006.

Stohl, A., Seibert, P., Arduini, J., Eckhardt, S., Fraser, P., Greally, B. R., Lunder, C., Maione, M., Mhle, J., O’Doherty, S., Prinn, R. G., Reimann, S., Saito, T., Schmidbauer, N., Simmonds, P. G., Vollmer, M. K., Weiss, R. F., and Yokouchi, Y.: An analytical inversion method for determining regional and global emissions of greenhouse gases: Sensitivity studies and application to halocarbons, Atmos. Chem. Phys., 9, 1597-1620, 2009, http://www.atmos-chem-phys.net/9/1597/2009/.

Thrane, K. E. and Mikalsen, A.: High-volume sampling of airborne polycyclic aromatic-hydrocarbons using glass-fiber filters and polyurethane foam, Atmos. Environ., 15, 909-918, 1981.

Tuinstra, W., Hordijk, L., and Kroeze, C.: Moving boundaries in transboundary air pollution co-production of science and policy under the convention on long range transboundary air pollution, Global Environ. Chang., 16, 349-363, doi:10.1016/j.gloenvcha.2006.03.002, 2006.

UNECE: The 1979 Geneva convention on long-range transboundary air pollution, available at: http://www.unece.org/env/lrtap, 2009.

UNEP: Final act of the conference of plenipotentaries on the Stockholm convention on persistent organic pollutants, in: United Nations Environment Program, Stockholm, Sweden, 2001.

Venier, M. and Hites, R. A.: Flame retardants in the atmosphere near the great lakes, Environ. Sci. Technol., 42, 4745-4751, doi:10.1021/es800313z, 2008.

Wania, F. and Mackay, D.: Global fractionation and cold condensation of low volatility organochlorine compounds in polar-regions, Ambio, 22, 10-18, 1993.

Wania, F. and Mackay, D.: Tracking the distribution of persistent organic pollutants, Environ. Sci. Technol., 30, A390-A396, 1996.

Wania, F., Haugen, J. E., Lei, Y. D., and Mackay, D.: Temperature dependence of atmospheric concentrations of semivolatile organic compounds, Environ. Sci. Technol., 32, 1013-1021, 1998.

Wania, F. and Daly, G. L.: Estimating the contribution of degradation in air and deposition to the deep sea to the global loss of 
PCBs, Atmos. Environ., 36, 5581-5593, 2002.

Wania, F. and $\mathrm{Su}$, Y. S.: Quantifying the global fractionation of polychlorinated biphenyls, Ambio, 33, 161-168, 2004.

Wania, F.: Potential of degradable organic chemicals for absolute and relative enrichment in the Arctic, Environ. Sci. Technol., 40, 569-577, doi:10.1021/es051406k, 2006.

Wesely, M. L.: Parameterization of surface resistances to gaseous dry deposition in regional-scale numerical-models, Atmos. Environ., 23, 1293-1304, 1989.

Willett, K. L., Ulrich, E. M., and Hites, R. A.: Differential toxicity and environmental fates of hexachlorocyclohexane isomers, Environ. Sci. Technol., 32, 2197-2207, 1998.
Yttri, K. E., Aas, W., Bjerke, A., Cape, J. N., Cavalli, F., Ceburnis, D., Dye, C., Emblico, L., Facchini, M. C., Forster, C., Hanssen, J. E., Hansson, H. C., Jennings, S. G., Maenhaut, W., Putaud, J. P., and Tørseth, K.: Elemental and organic carbon in PM10: a one year measurement campaign within the European Monitoring and Evaluation Programme EMEP, Atmos. Chem. Phys., 7, 5711-5725, 2007,

http://www.atmos-chem-phys.net/7/5711/2007/.

Zhang, L. S., Ma, J. M., Venkatesh, S., Li, Y. F., and Cheung, P.: Modeling evidence of episodic intercontinental long-range transport of lindane, Environ. Sci. Technol., 42, 8791-8797, doi:10.1021/es801271b, 2008. 